\title{
Osmotolerant Plant Growth Promoting Bacterial Inoculation Enhances the Antioxidant Enzyme Levels of Tomato Plants Under Water Stress Conditions
}

\author{
G. Hema Bindu ${ }^{1}$, G. Selvakumar ${ }^{1 *}$, K.S. Shivashankara ${ }^{1}$ and N. Sunil Kumar ${ }^{2}$ \\ ${ }^{1}$ ICAR- Indian Institute of Horticultural Research, Hesaraghatta Lake Post, \\ Bengaluru-560089, Karnataka, India \\ ${ }^{2}$ Gokaraju Rangaraju Institute of Engineering and Technology, Hyderabad, Telangana, India \\ *Corresponding author
}

\section{A B S T R A C T}

Drought stress alters productivity of crops in general and horticultural crops in particular resulting in poor quality produce and reduced yields. When plants are exposed to severe water stress, they suffer from membrane destabilization and general nutrient imbalances

\section{Keywords}

Osmotolerant plant growth, Bacterial inoculation

Article Info

Accepted:

20 December 2017

Available Online:

10 January 2018 that alter their physiology and defence mechanisms. The antioxidant enzyme system of plants plays an important role in the scavenging of Reactive Oxygen Species (ROS) that accumulate during stress, and is the first line of defence to counter the deleterious stress effects. In this study the effects of osmotolerant bacterial inoculation on the protein content, antioxidant enzymes viz., catalase (CAT), peroxidase (POX), superoxide dismutase (SOD), glutathione reductase (GR) and the proline content of tomato plants subjected to continued water stress for a period of $144 \mathrm{~h}$, was determined. It was evident that across bacterial treatments, plants inoculated with osmotolerant rhizobacterial strains recorded elevated levels of antioxidant enzymes compared to the uninoculated plants. But the isolates showed variability in enhancing the levels of the different antioxidant enzymes studied. Under water stressed conditions plants inoculated with Enterobacter P-68, Enterobacter P-46, Enterobacter P-39 and Bacillus G-4 recorded the highest activities of peroxidase, superoxide dismutase, catalase and glutathione reductase respectively, while plants inoculated with Bacillus amyloliquefaciens P-72 recorded the highest levels of proline accumulation.

\section{Introduction}

Environmental stresses induce alterations in the growth patterns and metabolism of plant species thereby altering their yield potential. Among the environmental stresses the lack of water can significantly affect plant growth and productivity (Kramer 1980). It is well established that drought has a profound impact on agricultural systems, and therefore the capacity of plants to withstand drought stress is of immense economic importance (Shao 2008). With diminishing fresh water resources available for agriculture, the pressing need of the moment is to sustain crop yields with the available water resources. Deficit water stress causes several visible changes in plant morphology like reduced shoot length, shoot 
weight, leaf area, leaf size, longevity and number of leaves per plant (Yordanov, 2007). But at the in planta level, water stress leads to the formation of reactive oxygen species (ROS) and alteration of water relationships within the plant. The extent to which plants can avoid or buffer these physiological processes determines their degree of resistance to water stress. Under drought stress, Abscisic acid (ABA) production by plants stimulates the closure of the stomatal guard cells to reduce water loss (Ajay et al., 2002).

This process also decreases the $\mathrm{CO}_{2}$ availability for photosynthesis thereby resulting in an imbalance between the generation and the use of electrons, leading to the overproduction of reactive oxygen species (ROS). The free ROS attack the biological structures, damage DNA, oxidize amino acids and proteins, and lead to lipid peroxidation (Asada 1999; Johnson, 2003). To overcome ROS toxicity, plants produce enzymatic and non-enzymatic antioxidants that scavenge oxygen species (Vranová et al., 2002). The ROS scavengers are primarily antioxidant enzymes (Demiral and Turkan, 2005; Khan and Panda, 2008). Antioxidant enzymes, like superoxide dismutase (SOD, EC 1.15.1.1), catalase (CAT, EC 1.11.1.6) and guaiacol peroxidase (GPX, EC 1.11.1.7) ensure the scavenging of ROS in the plant system.

The first lines of antioxidant defence mechanism of the plant are the enzymatic antioxidants, which neutralize the superoxide anion and hydrogen peroxide $\left(\mathrm{H}_{2} \mathrm{O}_{2}\right)$. Super oxide dismutase catalyses $\mathrm{O}_{2} \cdot$ - dismutation and is considered the most effective intracellular enzymatic antioxidant being present in all subcellular compartments prone to ROS mediated oxidative stress (Gill and Tuteja 2010). The different affinities of peroxidases and catalases for $\mathrm{H}_{2} \mathrm{O}_{2}$ suggest that the functions of these two different classes of $\mathrm{H}_{2} \mathrm{O}_{2}$-scavenging enzymes are different. Catalases are involved in the removal of excess $\mathrm{H}_{2} \mathrm{O}_{2}$, whereas peroxidases are mainly involved in fine modulation of ROS (Noctor and Foyer, 1998). The $\mathrm{H}_{2} \mathrm{O}_{2}$ can also be degraded by the activity of GPX activity, which has additional roles in structural cell wall modifications and production of secondary metabolites with antimicrobial activity. It is universally accepted that plants with high induced antioxidant enzyme levels have better tolerance and resistance to oxidative damage (Parida and Das, 2005). The proline accumulated in plants under water stress also protects the cells by balancing the osmotic potential of the cytosol with that of the vacuole and external environment (Pireivatloum et al., 2010).

Interactions between plants and rhizobacteria occur either through symbiotic or associative processes, with distinct degrees of proximity between roots and the surrounding soil. Abiotic stress alleviation in plants by rhizobacterial interventions has gained momentum over the years with the discovery of the phenomena of Induced Systemic Tolerance (IST) and its role in maintaining the plant homeostasis (Yang at al. 2008).Amongst the rhizobacterial plant homeostasis regulating mechanisms the removal of ROS in the plant system by the enhancement of anti-oxidant enzymes through rhizobacterial inoculation is important. Therefore this study attempts to decipher the improvement in the plants ability to scavenge ROS as a result of rhizobacterial inoculation.

\section{Materials and Methods}

\section{Bacterial strains and design of the experiment}

The bacterial strains viz., Bacillus amyloliquefaciens (P72), Pseudomonas sp. (CP3), Bacillus spp., (CP2, G4, R7), 
Enterobacter spp. (P39, P41, P46, P68, P76) and the Actinobacterial strains Citricococcus zhaciaensis (B-4), were originally isolated from the rhizosphere of different crops grown in arid conditions on PEG 8000/ mannitol supplemented media at osmotic potentials ranging from -2.1 to $-2.92 \mathrm{MPa}$, and maintained in the Division of Soil Science and Agricultural Chemistry, ICAR-IIHR, Bengaluru, India (Bindu et al.,2017). The tomato cultivar Arka Saurabh that is highly susceptible to deficit water stress was used for this experiment. Seeds were surface sterilized by soaking in $0.01 \%$ mercuric chloride for 60 secs and rinsed thoroughly by multiple passages in sterile distilled water. The surface sterilized seeds were transferred aseptically to Erlenmeyer flasks containing exponential cultures of individual bacterial isolates and kept overnight for bacterization. Seeds soaked in sterile uninoculated nutrient broth served as a control. The overnight bacterized and control seeds were then sown in protrays containing sterile cocopeat and maintained under polyhouse conditions for 21days. The seedlings raised in the above manner were transferred to plastic pots (14 inch diameter) containing soil and FYM in a 1:1 ratio, and maintained in a polyhouse under ambient conditions. The experimental design consisted of thirteen treatments and three replications. Plants were regularly watered for a period of thirty days after which they watering was withdrawn for a continuous period of $72 \mathrm{~h}$ during which the mild symptoms of water stress such as drooping of leaves appeared, the withdrawal of water was continued subsequently for another continuous period of $72 \mathrm{~h}$ during which the severe symptoms of water stress manifested in the form of wilting of the plants. During this stage, leaf samples were collected from individual plant samples and used for the analysis of the anti-oxidant enzymes viz., catalase (CAT), peroxidase (POX), superoxide dismutase (SOD), glutathione reductase (GR), protein and proline contents. Leaf samples were frozen in liquid nitrogen immediately after harvesting and stored at $-20^{\circ} \mathrm{C}$ until the enzyme assays were conducted.

\section{Estimation of protein content}

For the estimation of protein content, one gram of individual leaf sample was homogenized in $3 \mathrm{ml}$ of $0.05 \mathrm{M}$ Na phosphate buffer ( $\mathrm{pH}$ 7.8) containing $1 \mathrm{mM}$ EDTA (Ethylene Diamine Tetra Acetic acid) and 2\% (w/v) Polyvinylpyrrolidone (PVP). The homogenates were centrifuged at $13000 \mathrm{~g}$ for $40 \mathrm{~min}$ at $4^{\circ} \mathrm{C}$ and the supernatant was used for estimation of the protein content. The total soluble protein contents were determined spectrophotometrically (Shimadzu UV-1600) according to Bradford 1976.

\section{Preparation of leaf samples for estimation of anti-oxidant enzyme activity}

Leaf tissue $(0.5 \mathrm{~g})$ was extracted in $5 \mathrm{ml}$ of 50 $\mathrm{mM}$ potassium phosphate buffer $(\mathrm{pH}$ 7.0). Ethylene diaminetetra acetic acid and Polyvinylpyrrolidone (EDTA and PVP). The homogenate was centrifuged at 10,000 rpm for $15 \mathrm{~min}$ at $4^{\circ} \mathrm{C}$ and the supernatants were used for assay of the of anti-oxidant enzymes. All enzyme activities were determined at $4{ }^{\circ} \mathrm{C}$.

\section{Estimation of superoxide dismutase (SOD) activity}

SOD (EC 1.15.1.1) activity was estimated by the method of $\mathrm{Du}$ and Bramlage (1994). Individual assay mixtures containing $50 \mathrm{mM}$ potassium phosphate buffer ( $\mathrm{pH} 7.8$ ), $13 \mu \mathrm{M}$ methionine, $75 \mu \mathrm{M}$ Nitro blue tetrazolium chloride(NBT), $2 \mu \mathrm{M}$ riboflavin, $10 \mu \mathrm{M}$ EDTA and $20 \mu \mathrm{l}$ of leaf enzyme extract were incubated under light and dark conditions respectively for $30 \mathrm{~min}$. The inhibition of photo-oxidation of NBT under fluorescent light in presence of riboflavin and methionine 
was measured at $560 \mathrm{~nm}$ and expressed in units per $\mathrm{mg}$ of protein. One unit of SOD activity was defined as the amount of enzyme that inhibited the NBT photo reduction by 50 $\%$ under assay conditions.

\section{Peroxidase (POD)}

POD (EC 1.11.1.7) activity was determined by the method of Chander (1990). The assay mixture $(3 \mathrm{ml})$ contained $50 \mathrm{mM}$ potassium phosphate buffer ( $\mathrm{pH} 7.0), 0.2 \mathrm{~mL}$ of $o$ phenylenediamine and $30 \mu \mathrm{l}$ of leaf enzyme extract. The reaction was initiated by the addition of hydrogen peroxide $\left(\mathrm{H}_{2} \mathrm{O}_{2}\right)$. The peroxidase activity was estimated by measuring the $\mathrm{H}_{2} \mathrm{O}_{2}$ dependent oxidation of $\mathrm{O}$ phenylenediamine at $450 \mathrm{~nm}$ and expressed in units per $\mathrm{mg}$ of protein using the standard enzyme (Sigma-Aldrich).

\section{Catalase (CAT)}

CAT (EC 1.11.1.6) activity was determined by the procedure of Masia (1998). The assay mixture $(3.0 \mathrm{~mL})$ contained $50 \mathrm{mM}$ potassium phosphate buffer ( $\mathrm{pH} 7.0$ ), $0.3 \mathrm{~mL}$ of hydrogen peroxide $\left(\mathrm{H}_{2} \mathrm{O}_{2}\right)$ and $100 \mu \mathrm{L}$ of the leaf enzyme extract. The reduction in $\mathrm{H}_{2} \mathrm{O}_{2}$ by the enzyme extract was estimated by reading the reduction of absorbance $240 \mathrm{~nm}$ and expressed in units per $\mathrm{mg}$ of protein.

\section{Glutathione reductase (GR)}

GR (EC 1.6.4.2) activity was estimated by the procedure of Mavis and Stellwagen (1968). The assay mixture $(3.0 \mathrm{~mL})$ contained $50 \mathrm{mM}$ ( $\mathrm{pH} 7.0$ ), potassium phosphate buffer $0.35 \mathrm{~mL}$, ß-Nicotinamide Adenine Dinucleotide Phosphate, reduced form (NADPH) and 100 $\mu \mathrm{L}$ of the leaf enzyme extract. The reduction in NADPH was recorded by measuring the absorbance at $340 \mathrm{~nm}$. A unit of glutathione reductase activity was expressed as the change in absorbance per min and the specific activity was expressed as enzyme units/mg of protein.

\section{Estimation of proline content}

Free proline was extracted from $200 \mathrm{mg}$ of leaf sample in $3 \%(\mathrm{w} / \mathrm{v})$ aqueous sulfosalicylic acid and estimated by using ninhydrin reagent according to the method of Bates et al., (1973). The organic toluene phase containing the chromophore was separated and the absorbance of red colour developed was read at $520 \mathrm{~nm}$. The proline concentration was determined using a calibration curve and expressed as $\mathrm{mg} \mathrm{g}^{-1}$ of fresh weight.

\section{Results and Discussion}

In general it could be observed that in leaf samples collected after the imposition of $144 \mathrm{~h}$ of water stress the protein contents and antioxidant enzyme levels were higher in the stressed plants compared to the non-stressed plants. Similarly the bacterial inoculation significantly improved the anti-oxidant enzyme levels and protein compared to the uninoculated controls. But the bacterial inoculation produced a differential response in terms of the elevated levels of various antioxidant enzymes, in stressed plants. There seemed to be a preferential stimulation of a particular anti-oxidant scavenging enzyme by individual bacterial strains. Under water stressed conditions plants inoculated with the bacterium Bacillus amyloliquefaciens P-72 recorded the highest protein content followed by the isolate Bacillus sp.R-2 (Fig.1). A different trend was observed with respect to the anti-oxidant enzyme peroxidase (Fig.2), where water stressed plants inoculated with Enterobacter P-68 recorded the highest peroxidase activity, followed by Bacillus $s p$ R-2. The superoxide dismutase activity (Fig.3) was higher in stressed plants inoculated with Enterobacter P-46 followed by Bacillus amyloliquefaciens P-72, while the catalase activity of stressed plants was highest in the case of inoculation with Enterobacter P-39 followed by Enterobacter P-46 (Fig.4). Water stressed plants inoculated with Bacillus G-4 
recorded the highest levels of glutathione reductase compared to the uninocuated controls and the other isolates (Fig.5). Water stress resulted in the multifold increase in proline concentration in leaf tissues of inoculated plants compared to the uninoculated plants indicating that proline was produced by the plants as response to the stress and inoculation with PGPR further improved stress response of the seedlings in terms of proline content. Plants inoculated with Bacillus amyloliquefaciens P-72 accumulated the highest levels of proline followed by Bacillus sp. CP-2 (Fig.6).

The effects of water stress on plants are manifold and much of the injury to plants under abiotic stress is due to oxidative damage at the cellular level, which is the result of imbalance between the formation of reactive oxygen species (ROS) and their detoxification potential. ROS can also act as second messengers involved in the stress signal transduction pathway (Chamnongpol et al., 1998), but excessive ROS production can cause oxidative stress, which damages plants by oxidizing photosynthetic pigments, membrane lipids, proteins and nucleic acids (Yordanov et al., 2000). To keep the levels of active oxygen species under control, plants have non-enzymatic and enzymatic antioxidant systems to protect cells from oxidative damage (Mittler, 2002).

The antioxidant enzymes viz.,catalase (CAT), peroxides (POX), superoxide dismutase (SOD), glutathione peroxidase (GPX) and ascorbate peroxidase (APX) scavenge the reactive free radicals (Simova-Stoilova et al., 2008), the non-enzymatic ROS scavenging components contain cysteine, glutathione and ascorbic acid (Kaushal and Wani, 2015). The activities of these enzymes have been shown to be elevated even under mild water stress (Jian and Zhang, 2002).CAT, APX, POD are enzymes that catalyse the conversion of $\mathrm{H}_{2} \mathrm{O}_{2}$ to water and $\mathrm{O}_{2}$ (Gratao et al., 2005). Superoxide dismutases (SODs), a group of metalloenzymes, are considered as the first defence against ROS, being responsible for the dismutation of $\mathrm{O}_{2}{ }^{-}$to $\mathrm{H}_{2} \mathrm{O}_{2}$ and $\mathrm{O}_{2}$ (Gill and Tuteja 2010).

Fig.1 Effect of osmotolerant bacterial inoculation on protein content of tomato plants (mg per 100g FW)

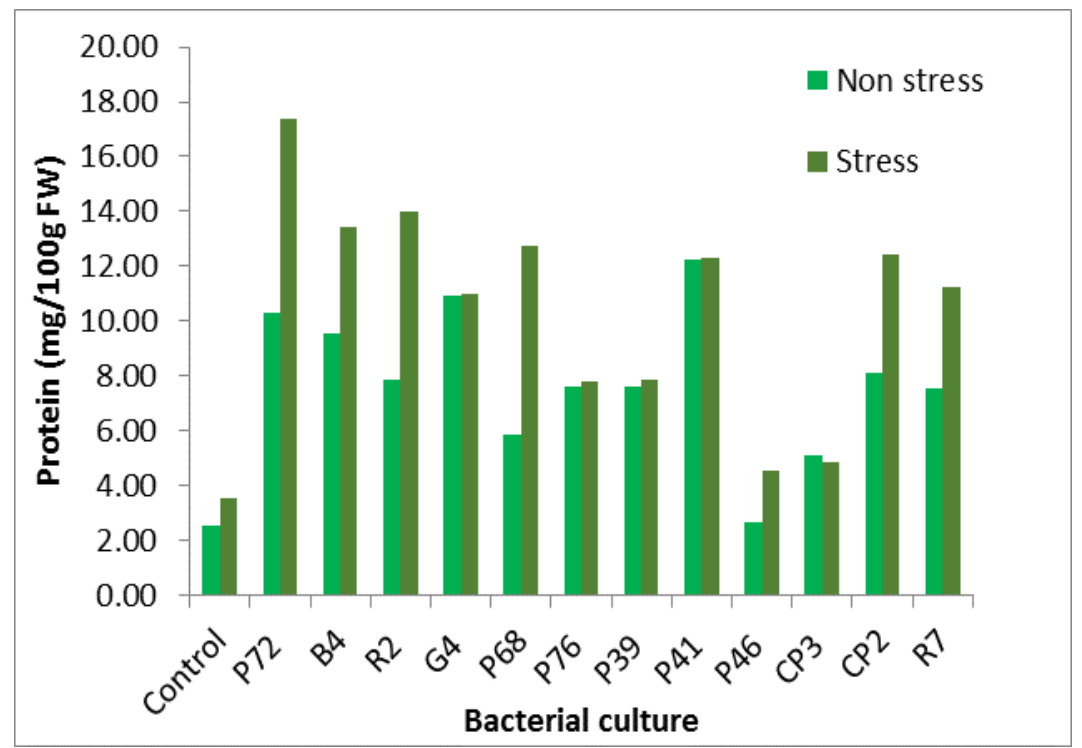


Fig.2 Effect of osmotolerant bacterial inoculation on peroxidase activity (Units/mg protein)

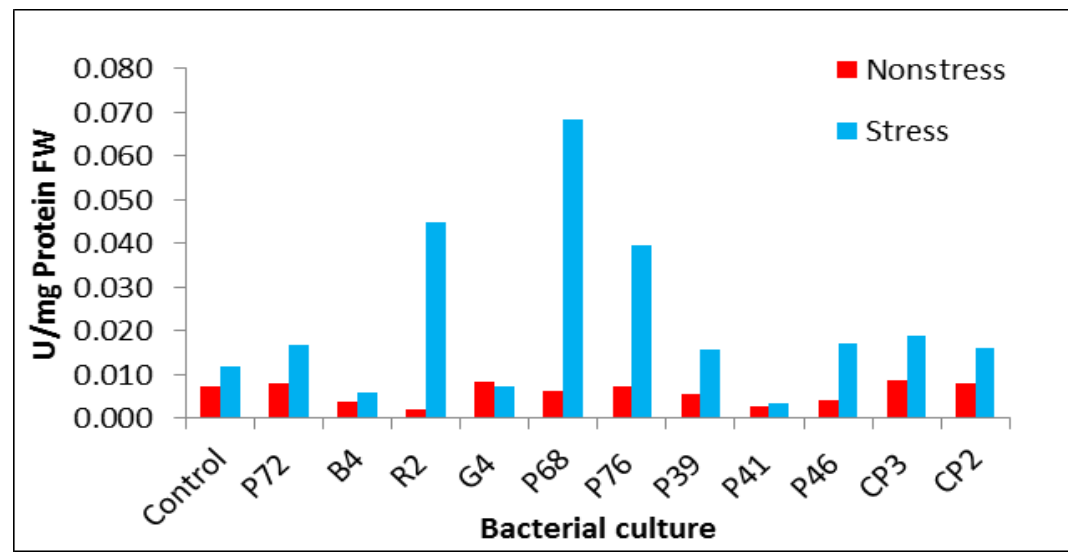

Fig.3 Effect of osmotolerant bacterial inoculation on super oxide dismutase activity (Units/mg protein)

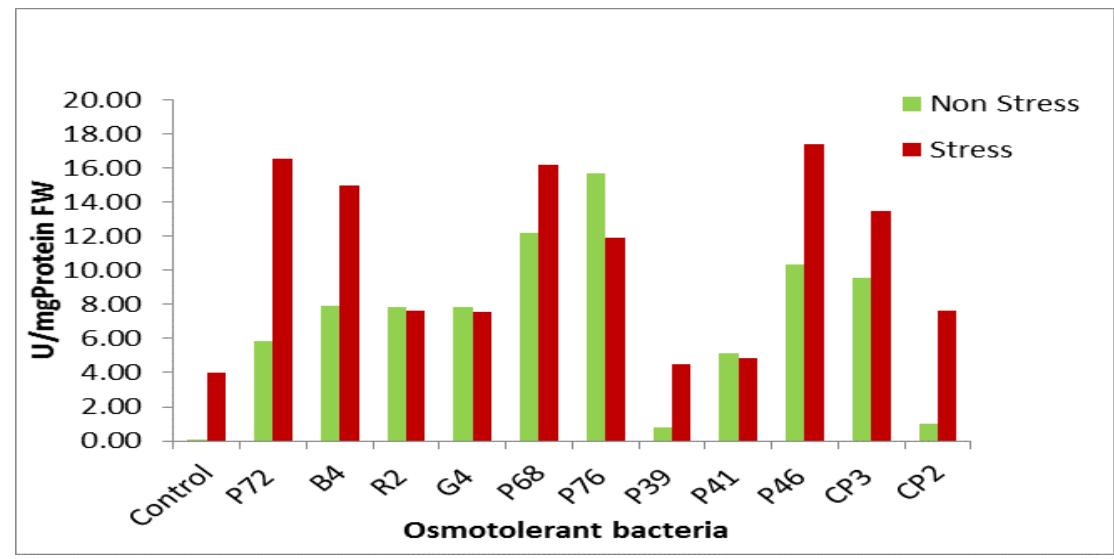

Fig.4 Effect of different osmotolerant bacterial inoculation on catalase activity (Units/mg Protein)

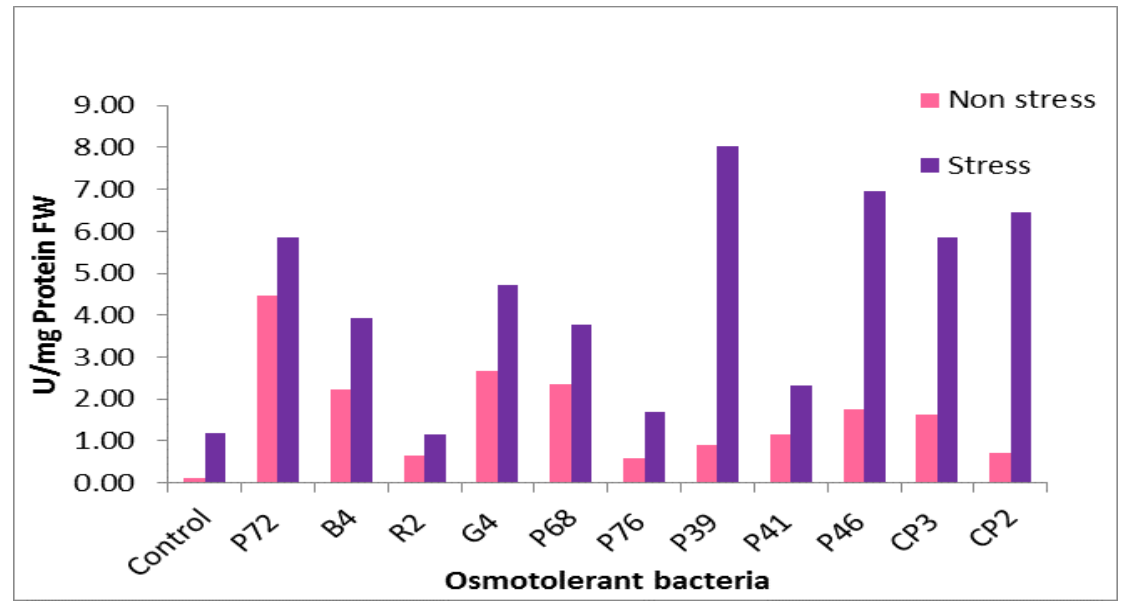


Fig.5 Effect of osmotolerant bacterial inoculation on Glutathione reductase activity (U/mg of protein)

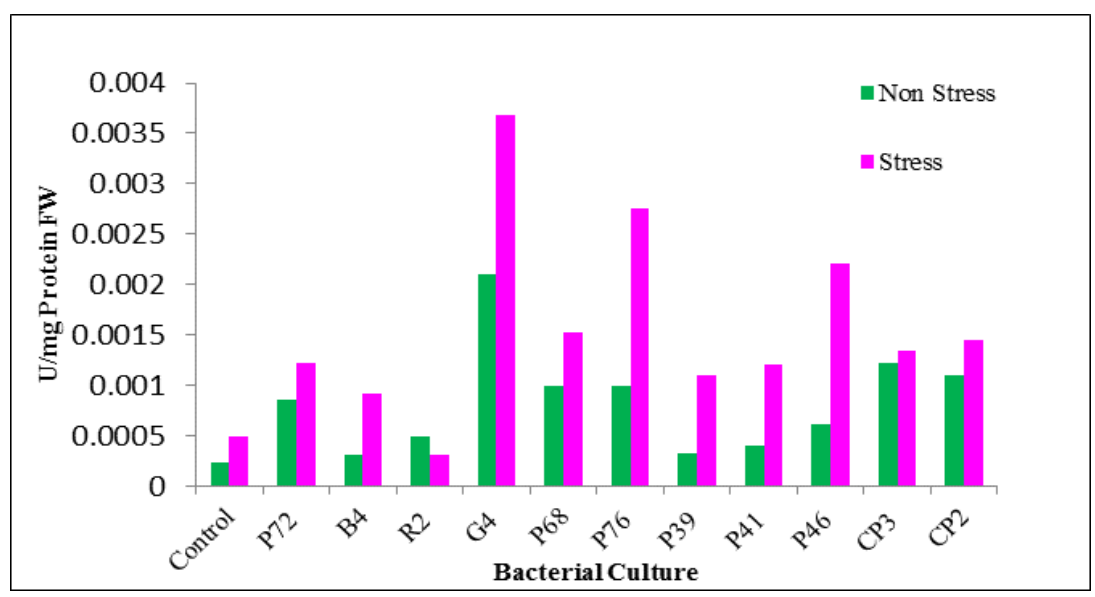

Fig.6 Effect of osmotolerant bacterial inoculation on proline content (mg/100 $\mathrm{g}$ fresh weight)

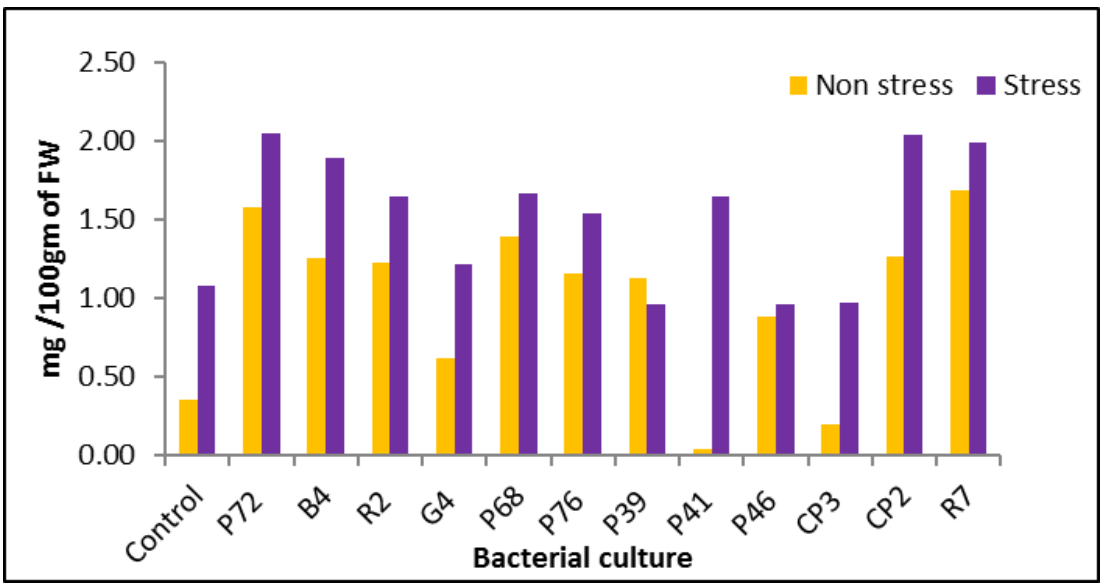

In the present study, the levels of all the antioxidant enzymes were found to be higher in the inoculated plants compared to the uninoculated plants. Similar results were recorded in earlier studies where the catalase and peroxidase levels of green gram were elevated by the application of plant growth promoting Pseudomonas strains (Saravanakumar et al., 2011), similarly a significant increase in the GPX and APX enzyme activities of basil plants (Ocimum basilicum L.) treated with Pseudomonas sp. was reported by Heidari and Golpayegani (2011). The inoculation of plant growth promoting $P$. jessenii R62, $P$. synxantha $\mathrm{R} 81$ and A. nitrogua-jacolicus strainYB3 and strain YB5 used as a consortium was found to enhance the plant growth and induction of SOD, CAT, peroxidase (POD), APX and lower the level of $\mathrm{H}_{2} \mathrm{O}_{2}$, malondialdehyde (MDA) in rice (O. sativa) under drought stress conditions compared to control (Gusain et al., 2015).

Proline and soluble sugars are the key osmolytes contributing towards osmotic adjustment under water stressed conditions. Under stress conditions proline can serve as a mediator of osmotic adjustment, a stabilizer of subcellular structures, an eliminator of free 
radicals, and a buffer of the redox potential besides forming an important component of cell-wall proteins (Schobert and Tschesche, 1978; Hare and Cress 1997; Nanjo et al., 1999). Proline accumulation during oxidative stress helps the plants to decrease oxidative damage (Nayer and Reza 2008). In an earlier study the inoculation of plant growth promoting Pseudomonas strains was also found to increase the proline content under drought stress. This may be due to the up regulation of the proline biosynthesis pathway which helps in maintaining the cell water status besides protecting membranes and proteins from stress (Sandhya et al., 2010). In the present study also it was observed that the proline accumulation was higher in the inoculated plants compared to the uninoculated plants.

The inoculation of plant growth promoting rhizobacteria has been found effective under drought stress environment for increasing the productivity of crops (Rincon et al., 2008). Similarly it has also been shown that the inoculation of plant growth promoting bacteria has been shown to significantly elevate of the anti-oxidant enzyme levels of lettuce plants exposed to high levels of salinity (Han and Lee 2005). Therefore, an understanding of the interactions between plants and microorganisms that confer stress tolerance properties is required. In the present study the inoculation of osmotolerant bacterial strains was found to increase the antioxidant stress enzyme levels of tomato plants exposed to acute levels of water stress for a period of 144 hours, compared to the uninoculated plants, which is indicative of their ability to induce stress tolerance potential. But the isolates showed variability in enhancing the levels of the different antioxidant enzymes studied. But nevertheless this study clearly brings out the ability of osmotolerant rhizospheric bacteria to elevate the levels of antioxidant enzymes in water stressed tomato plants.

\section{Acknowledgement}

This work was funded by the Indian Council of Agricultural Research, under the National Innovations on Climate Resilient Agriculture (NICRA) project.

\section{References}

Ajay, A., Sairam, R.K., Srivastava, G.C. 2002. Oxidative stress and antioxidative system in plants, Curr. Sci. 1227-1238.

Asada, K. 1999. The water-water cycle in chloroplasts: scavenging of active oxygens and dissipation of excess photons. Ann. Rev. Plant Biol. 601639.

Bates, L.S., Walden, R.P., and Teare, I.D. 1973. Rapid determination of free proline for water studies. Plant Soil. 39: 205-208.

Bradford, M.M. 1976. A rapid and sensitive method for the quantisation of microgram quantities of protein utilizing the principle of protein-dye binding, Anal. Biochem. 248-254.

Chamnongpol, S., Willekens H., Moeder W., Langebartels C., Sandermann H., Van M.M., Inze D., Van C.W. 1998. Defense activation and enhanced pathogen tolerance induced by $\mathrm{H}_{2} \mathrm{O}_{2}$ in transgenic tobacco. Proc. Natl. Acad. Sci. U S A95: 5818-5823.

Demiral, T., and I. Turkan. 2005. Comparative lipid per oxidation, antioxidant defense system and proline content in roots of two rice cultivars differing in salt tolerance. Environ. Exp. Bot. 53: 247-257.

Du, Z. and Bramlage, W.J. 1994. Superoxide dismutase activities in senescing apple fruit (Malus domesticva Borkh.). J. of Food Sci.59:581-584.

Gill, S.S., and Tuteja N. 2010. Reactive oxygen species and antioxidant machinery in abiotic stress tolerance in 
crop plants. Plant Physiol. Biochem. 48: 909:930.

Gratao, P.L., Polle A., Lea P.J., Azevedo R.A. 2005. Making the life of heavy metalstressed plants a little easier. Funct. Plant Biol. 32: 481-494.

Gusain, Y. S., Singh, U. S., and Sharma, A. K. 2015. Bacterial mediated amelioration of drought stress in drought tolerant and susceptible cultivars of rice (Oryza sativa L.). Afr. J. Biotechnol. 14: 764-773.

Han, H.S., and Lee, K.D. 2005. Plant growth promoting rhizobacteria effect on antioxidant status, photosynthesis, mineral uptake and growth of lettuce under soil salinity. J Agri. Biol. Sci. $1: 210-215$

Hare, P.D., and Cress, W.A. 1997. Metabolic implications of stress-induced proline accumulation in plants, Plant Growth Regul. 21:79-102.

Heidari, M., Mousavinik, S. M., and Golpayegani, A. 2011. Plant growth promoting rhizobacteria (PGPR) effect on physiological parameters and mineral uptake in basil (Ociumum basilicm L.) under water stress. ARPN J Agric. Biol. Sci. 6:6-11.

Hema Bindu, G., Selvakumar G., and Sunil Kumar, N. 2017. In vitro evaluation of the antagonistic traits and potential of osmotolerant rhizobacteria against fungal plant pathogens. Trends in Bioscience. 10 (22): 4414-4417.

Jiang, M., Zhang J. 2002. Water stressinduced abscisic acid accumulation triggers the increased generation of reactive oxygen species and upregulates the activities of antioxidant enzymes in maize leaves. J Exp Bot. 53:2401-10.

Johnson, S., Doherty, S.J., Croy, R.R.D. 2003. Biphasic superoxide generation in potato tubers. A self-amplifying response to stress, Plant Physiol. 122: 747-756.

Kaushal, M., and Wani, S. P. 2016. Plantgrowth-promoting rhizobacteria: drought stress alleviators to ameliorate crop production in drylands. Ann. Microbiol. 66: 35-42.

Khan, M.H. and S.K. Panda. 2008. Alterations in root lipid per oxidation and antioxidative responses in two rice cultivars under NaCl-salinity stress. Acta Physiol. Plant 30: 81-89.

Kramer, P.J., 1980. Drought stress and the origin of adaptation, in: N.C. Turner, P.J. Kramer (Eds.) Adaptation of Plants to Water and High Temperature Stress. John Wiley and Sons. New York. USA pp. 7-20.

Masia, A. 1998. Superoxide dismutase and catalase activities in apple during ripening and post-harvest and with special reference to ethylene. Physiol. Plantarum. 104: 668-672

Matysik, J., Alia, A., Bhalu, B., and Mohanty, P. 2002. Molecular mechanisms of quenching of reactive oxygen species by proline under stress in plants. Curr. Sci. 82:525- 532.

Mavis, R. D., and Stellwagen, E. 1968. Purification and subunit structure of glutathione reductase from bakers' yeast. J. Biol. Chem. 243: 809-814.

Mittler, R. 2002. Oxidative stress, antioxidants and stress tolerance. Trends Plant Sci. 7: 405-410.

Nanjo, T., Kobayashi, M., Yoshiba, Y., Sanada, Y., Wada, K., Tsukaya, H., Kakubari, Y., Yanaguchi-Shinozaki, K., Shinozaki, K. 1999. Biological functions of proline in morphogenesis and osmotolerance revealed in antisense transgenic Arabidopsis thaliana. Plant J. 18: 185-193.

Nayer, M., and Reza, H. 2008. Droughtinduced accumulation of soluble sugars 
and proline in two maize varieties. W. J. App. Sci: 448-453

Noctor, G., Foyer, C. H.1998. Ascorbate and glutathione: keeping active oxygen under control. Annu. Rev. Plant Physiol. Plant Mol. Biol. 49, 249- 279.

Parida, A.K., and A.B. Das. 2005. Salt tolerance and salinity effects on plants. Ecotoxicol. Environ. Safety. 60: 324349.

Pireivatloum, J., Qasimov N. and Maralian H. 2010. Effect of soil water stress on yield and proline content of four wheat lines. Afr. J. Biotech.9: 36-40.

Rincón, A., Valladares, F., Gimeno, T. E., and Pueyo, J. J. 2008. Water stress responses of two Mediterranean tree species influenced by native soil microorganisms and inoculation with a plant growth promoting rhizobacterium. Tree Physiology. 28: 1693-1701.

Sandhya, V., Ali, S.K.Z., Grover, M., Reddy, G., Venkateswaralu, B., 2010. Effect of plant growth promoting Pseudomonas spp. on compatible solutes antioxidant status and plant growth of maize under drought stress. Plant Growth Regul. 62: 21-30.

Saravanakumar, D., Kavino, M., Raguchander, T., Subbian, P., and Samiyappan, R. 2011. Plant growth promoting bacteria enhance water stress resistance in green gram plants. Acta Physiol Plant. 33: 203-209.
Schobert, B., and Tschesche, H. 1978. Unusual solution properties of proline and its interactions with proteins. Biochem. Biophys. Acta 541: 240-277.

Shao, H.B., L.Chu, C.A. Jaleel., C.X. Zhao. 2008. Water-deficit stress-induced anatomical changes in higher plants. $\mathrm{C}$. R. Biol. 215-225.

Simova-Stoilova, L., Demirevska, K., Petrova, T., Tsenov, N., and Feller, U. 2008. Antioxidative protection in wheat varieties under severe recoverable drought at seedling stage. Plant Soil. Environ. 54:529-536.

Subhas Chander, M. 1990. Enzymatic properties association with resistance to rust and powdery mildew in peas. Indian J. Hortic. 47:341-345.

Vranová, V., D. Inzé and F. Van Breusegem. 2002. Signal transduction during oxidative stress. J. Exp. Bot. 53: 12271236.

Xu, P.L. Guo, Y.K., Bai, J.G., Shang, L., Wang, X.J. 2008. Effects of long-term chilling on ultrastructure and antioxidant activity in leaves of two cucumber cultivars under low light. Physiol. Plantarum.132: 467-478.

Yang, J., Kloepper, J. W., and Ryu, C. M. 2009. Rhizosphere bacteria help plants tolerate abiotic stress. Trends Plant Sci. 14: 1-4.

Yordanov, I., Velikova V., Tsonev T. 2000: Plant responses to drought, acclimation, and stress tolerance. Photosynthetica. 38: $171-186$.

\section{How to cite this article:}

Hema Bindu, G., G. Selvakumar, K.S. Shivashankara and Sunil Kumar, N. 2018. Osmotolerant Plant Growth Promoting Bacterial Inoculation Enhances the Antioxidant Enzyme Levels of Tomato Plants Under Water Stress Conditions. Int.J.Curr.Microbiol.App.Sci. 7(01): 28242833. doi: https://doi.org/10.20546/ijcmas.2018.701.337 